DOI: 10.1515/jolace-2015-0013

\title{
Causative get-constructions in the dialogued passages in F. Scott Fitzgerald's novels The Beautiful and Damned and Tender Is the Night as gender-conditioned structures
}

\author{
Rafał Gołąbek \\ Kazimierz Pułaski University of Technology and Humanities in Radom, Poland \\ Rafal.Golabek@wp.pl
}

\begin{abstract}
It goes without saying that in modern sociolinguistics there is a consensus with regard to the fact that the language of males and females differs. The initial sections of the article briefly address the peculiarities of gendered speech as to provide a theoretical background for checking whether the causative get is used similarly or differently by men and women in the two of F. Scott Fitzgerald's novels: The Beautiful and Damned and Tender Is the Night. The basic expectation formed is that the motifs for triggering the use of causative get are of social rather than structural nature. Before the analysis is carried out, the group of the English periphrastic causatives are sketchily characterized. Generally, what has been found is that there is a clear, socially-motivated pattern of how F. Scott Fitzgerald uses the causative get in the dialogued occurrences in his two novels. Get is a characteristic of men's talk, but it is also the expected form while female characters address male ones - hence the verb is labelled as "masculine" get. Moreover, it has been discovered that there does not seem to be any particular pattern in either the speaker's mood or the speaker's attitude expressed that would trigger the use of the causative verb in question. Yet, what seems to be a well-defined tendency, when it comes to the speaker-hearer power relation, is that the speaker usually assumes a more superior position than the hearer when he or she uses the causative verb. The superiority in most cases is strongly associated with masculinity. Hence, what is postulated is that the causative get is labelled not only as "masculine" but also as "superior".
\end{abstract}

\section{Keywords}

sociolinguistics, language and gender, periphrastic causative verbs, causative get, F. Scott Fitzgerald, power-relation, masculinity and superiority

\section{Introduction}

A major topic that has recently been in the focus of the sociolinguistic analysis is the mutual relations between the ways in which particular languages are used and the social roles performed by men and women who use those languages. It has been universally recognized that men and women speaking a given language use it differently. The question is about the source and the nature of those differences. Do the differences in the gendered speech derive from the language structure? Or, alternatively, do those differences simply reflect the manner in which the two sexes interact socially with each other? As Włodarczyk-Stachurska (2011a, p. 486) claims, the positive answer to the first question would basically confirm Whorfian hypothesis (1929), "acknowledging the close relationship between language and culture, maintaining that they were inextricably related so that you could not understand one without a knowledge of the other". In turn, as Włodarczyk-Stachurska claims, the affirmative answer to the latter question would undoubtedly emphasise the role of social dependencies as the factors playing the most significant role in shaping the language of men and women (ibid.). 
Whatever the source of those differences is, we might be tempted to investigate whether in English one can find variation in use, between men and women, in the periphrastic causative verbs such as cause, get, have, let and make. To this end, we shall first briefly present and discuss some views on the mutual bonds between language and gender and subsequently examine the occurrences of the causative get as found in the dialogued passages of the two novels by F. Scott Fitzgerald, The Beautiful and Damned and Tender Is the Night.

\section{Language and gender ${ }^{1}$}

Before we analyse the get-occurrences in the two above-mentioned novels with regard to the gender of the actors involved in communication, we shall briefly discuss the peculiarities of male and female speech. This will serve as a background to our subsequent analysis. It has been noted by numerous scholars that women's speech differs from the speech of men (for details see, for example, Baron, 1986; Arliss, 1991; Eckert \& McConnell-Ginet, 2003; Wardhaugh, 2006; or Włodarczyk-Stachurska, 2011a and 2011b). Moreover, as Wardhaugh says, there is some kind of bias as far as the language of men and speech of women are concerned. In the words of Wardhaugh (2006, p. 317), "men's speech usually provides the norm against which women's speech is judged. We could just as well ask how men's speech differs from that of women, but investigators have not usually gone about the task of looking at differences in that way."

Tannen (1990, p. 24-25) stresses that in general men tend to be more concerned with power whereas women with solidarity. For men, conversations are negations

in which people try to achieve and maintain the upper hand if they can, and protect themselves from others' attempts to put them down and push them around. Life, then, is a contest, a struggle to preserve independence and avoid failure.

In other words, as Grishaver (1997, p. 31) says, “men's major perceptions, as reflected in their language patterns, essentially involve the making of boundaries, the conquest and defence of territory and the maintenance of a pecking order". Therefore, the key concept in men's actions is independence. In contrast for women, as Tannen (1990, p. 25) says,

conversations are negotiations for closeness in which people try to seek and give confirmation and support, and to reach consensus. They try to protect themselves from others' attempts to push them away. Life, then, is a community, a struggle to preserve intimacy and avoid isolation. Though there are hierarchies in this world too, they are hierarchies more of friendship than of power and accomplishment.

What this means is that women's main motivations include bringing people closer and establishing and developing bonds with them. Following Tannen's way of reasoning, an important concept for women would be that of intimacy.

One might ask which other aspects make men's and women's speech different. Definitely, there seems to be a lot of stereotypes and false beliefs concerning the female speech. Romaine (1999, p. 167168) says that "women's conversations are routinely trivialized with the labels gossip, girl talk, bitching, and so on, whereas similar conversation among men are called shop talk". Therefore female talk is often looked down on whereas men's speech is often stereotypically assigned some qualities of a specialized jargon which may pertain to occupational or other specialized issues. Romaine adds that such

\footnotetext{
${ }^{1}$ As Wardhaugh (2006, p. 315) holds, "the current vogue is to use gender rather than sex" as the latter term "is to a very large extent biologically determined whereas gender is a social construct (but still one heavily grounded in sex)". Similar opinions are voiced by other contemporary linguists. Also in this paper, the term gender will be used rather than sex.
} 
judgments tend to reflect the different social values of men and women that are present in our societies. According to those judgments, what men do is often more important than what females do. Furthermore, she mentions that we often associate men's talk with being serious whereas women's talk is often stereotypically found to be trivial (ibid.). Yet, as Romaine says (1999, p. 168), Kipers (1987) found that women did not actually talk more than men about topics evaluated as trivial. What is interesting is that Kippers found out that nearly half of all the discussions undertaken entirely by men, entirely by women, and mixed-sex groups regarded topics that had been independently rated as trivial. Romaine adds that Coates (1996) found that some women were aware of some of the negative stereotypes associated with female speech and therefore often stressed the fact that they did not talk about "domesticky" or "girly" matters.

What is more, Wardhaugh (2006, p. 317) denies that women's speech is "gossip-laden, corrupt, illogical, idle, euphemistic, or deficient (...); nor is it necessarily more precise, cultivated, or stylish - or even less profane" than the speech of males. Nor do women gossip more than men do. Apparently, men gossip just as much as females do (for details see Pilkington, 1998), but as Wardhaugh (2006, p. 317) advocates, men's gossip is different. In his words, male gossip is "a kind of phatic small talk that involves insults, challenges, and various kinds of negative behavior to do exactly what women do by their use of nurturing, polite, feedback-laden, cooperative talk. In doing this, they achieve the kind of solidarity they prize. It is the norms of behavior that are different." This seems to be in accordance with what Litosseliti (2013, p. 39) claims. She believes that "whereas women may treat gossips as co-operative work that requires a lot of positive feedback and prompting, and avoid indirect disagreement, talk among men tends to contain little feedback and lot of open disagreement or criticism" (for details see also Coates, 1996, and Pilkington, 1998). Furthermore, according to Litosseliti, what the above means is that women prefer to pursue a conversation style based on solidarity, whereas men tend to engage in conversations in which competitiveness plays an important role (ibid.).

Additionally, male speech and female speech definitely differ with respect to vocabulary. Lakoff (1973) claims that women tend to use colour words such as, inter alia, aquamarine, lavender, magenta and mauve but most men do not. She also holds that adjectives such as adorable, charming, divine, lovely, or sweet are also frequently used by females, but are very rarely found in men's active vocabulary repertoire. Females are also found to have their own lexicon that is used in order to emphasize certain effects on them. Such words and expressions would include, for example, so good, such fun, lovely, divine, adorable, darling, and fantastic. Also Crystal $(1987$, p. 21) reports that women use intensifiers such as so or such (e.g. It was so busy) more often than men. Moreover, according to Crystal, women are said to use "exclamations such as Goodness me and Oh dear" with a higher frequency than men. The above seems to be confirmed in the words of Salzmann (1993, p. 184), who also claims that certain words in American English are used much more frequently by women than by men. Among such words, he lists "expressive adjectives that convey approval of admiration" such as, inter alia, charming, cute or sweet. Salzmann presents the view that "men are much more likely to phrase their approval or liking for something by using a neutral adjective such as fine, good, or great and reinforcing it, if necessary, with such an adverb as damn" as in „you were damn lucky not to have been killed!' (ibid.).

We have already referred to certain gender-based differentiations found in English. Let us now add some more characteristics of the male and female speech. According to Ritti (1973) girls are said to use expressions such as oh and wow more often than boys. Brend (1975) maintains that the intonation of men and women vary to some extent, claiming that women, more often than men, tend to use patterns normally associated with surprise and politeness. Lakoff $(1973,1975)$ characterizes at great length the speech of women. Among numerous peculiarities of women's speech, the linguist mentions so called "hedges", that is, lexemes such as well, $y^{\prime} k n o w, k i n d a$. She believes that such hedges are more often used by women than men. He says that 
women's speech seems in general to contain more instances of "well', "you know", "kind" and so forth: words that convey the sense that the speaker is uncertain about what he (or she) is saying, or cannot vouch for the accuracy of the statement (...). (Lakoff, 1975, p. 53-54)

Lakoff adds that these words are used "as an apology for making an assertion at all". Therefore, according to her, women use hedges because they avoid making direct statements. Lakoff also argues that women use "hypercorrect grammar" and more "super polite forms", (e.g. Would you mind...). Females also speak in "italics", that is, they emphasize certain words in order to stress the importance of what they are saying. Italics convey doubt about women's self-expressions and their fears "that words are apt to have no effect" (Lakoff 1975, p. 56).

Let us add that, as Wardhaugh (2006, p. 324) reports, many researchers agree that in conversations in which both men and women interact, men tend to speak more than women do. In addition, when men talk to men, their discussion often revolves around such topics as competition, sports, aggression, and doing things. In contrast, females talking to females focus mostly on such categories as the self, feelings, relations with others, family and home. What Wardhaugh says seems to be in line with the view of other researches presented above (cf. Tannen, 1990). Moreover, similarly to other researchers, Wardhaugh also reports that women "use more polite forms and more compliments than men. In doing so, they are said to be seeking to develop solidarity with others in order to maintain social relationships. On the other hand, men are likely to use talk to get things done" (ibid., cf. Lakoff 1973, 1975). However, Wardhaugh adds a cautionary note. The above-mentioned claims are only general tendencies. One should not forget that "men also try to bond and women also try to move others to action" (ibid.).

Another trait of women's speech reported by Lakoff is that they sometimes answer a question with a statement that has a rising terminal which reaches a level higher than the initial parts of the utterance. Such intonation is usually associated with questions rather than the falling intonation which is normally linked with making statements. She claims that women are more likely than men to use what she calls an "inappropriate question intonation", as in the frequently quoted example in which a husband asks: "When will dinner be ready?", and the wife replies with a rising intonation: "Oh ... around six o'clock...?" Lakoff says that the effect of such intonation is "as though one was seeking confirmation, though at the same time the speaker may be the only one who has the requisite information" $(1975, \mathrm{p}$. 17). According to Lakoff, such intonation patters signal uncertainty or lack of self-assertiveness of the women who use them.

For the same reason, she says that women often add a "tag question" to statements in sentences, such as, "I did lock the door, didn't I?" Lakoff $(1975$, p. 15) asserts that question tags are used "when the speaker is stating a claim, but lacks full confidence in the truth of that claim." The above seems to be in line with Włodarczyk-Stachurska (2011b, p. 116) who claims in a similar vein that

talking of language as used by women it seems that there is a great deal in women's speech in English that reflects extra politeness, one aspect of which is leaving a decision open, not imposing your mind, views or claims on the interlocutor. Note that two patterns seem to reveal this decisively; namely the abundant use of question tags ("The price of mincemeat is terrible, isn't it?"), and the high frequency of a rising intonation on utterances that are not syntactically questions.

Nevertheless, the above-mentioned claims about women's use of tag questions and the lack of confidence have been tested by other linguists (e.g. Dubois \& Crouch, 1975; Cameron et al., 1989; and Brower et al., 1979) who do not necessarily confirm those findings. However, as Wardhaugh (2006, p. 321) says, some "investigators did find, however, that the gender of the addressee was an important variable in determining how a speaker phrased a particular question".

Other researchers (e.g. Hartman, 1976; Poole, 1979) found that women more often than men use uncertainty verb phrases. This is especially true if the first person singular pronoun is combined with 
verbs of perception or cognition (e.g. I wonder if). What is more, Mulac et al. (2001) report that men use more words which refer to quantity, more directives (e.g. Write this down), more adjectives of judgmental character (e.g. good, dumb) and more I references than women. In contrast, according to the scholars, women make a greater use of more intensive adverbs (e.g. really, so), uncertainty verbs (e.g. seems to, maybe), and negations (e.g. not, never) than men. In their speech, they also refer to emotions more often than men. However, Mulac et al. did not find gender differences in the use of tag questions.

Crystal (1987, p. 21) pays attention to the strategies adopted by the men and women in cross-gender conversation. Crystal observes that

women have been found to ask more questions, make more use of positive and encouraging "noises" (such as $\mathrm{mhm}$ ), use a wider intonational range and more marked rhythmical stress, and make greater use of the pronouns you and we By contrast, men are much likely to interrupt (more than three times as much, in some studies), to dispute what has been said, to introduce more new topics into the conversation, and to make more declarations of fact or opinion. (ibid.)

As can be seen, some of Crystal's observations are in line with findings by some of the aforementioned researchers. Definitely, Crystal recognizes that there are conversational differences in the speech of males and that of females.

Let us also address the issue of swear words in the speech of the two genders. In the words of Włodarczyk-Stachurska (2011a, p. 491), "almost universally, today men feel freer to use swear words, while women were - until quite recently - merely limited to such exclamations as sugar and shoot". What this means is that men nowadays swear much more often than in the past. It is also observed that there is a trend in women to use taboo language which was not the case some time ago. WłodarczykStachurska (2011a) also quotes Mulac and Lundell (1986) as well as Mehl and Pennebaker (2003) who observe that men tend to use longer words, use more articles and make more references to locations.

Above we have briefly presented the most prominent differences between the language of men and women in English. This outline of gendered speech will serve as a background to our subsequent analysis. Since there appears to be a consensus with regard to the fact that the speech of males and females differs, we will check whether the causative get is used similarly or differently by men and women in the two of Fitzgerald's novels. This will be done by examining the dialogued occurrences found in the novels. Before we do that, the group of English periphrastic causatives will be sketchily addressed.

\section{Periphrastic causative verbs in English}

Causativity is one of the most controversial and often discussed issues in philosophy, philosophy of language and linguistics. Discussion over the analysis of English causative constructions has occupied a prominent space in modern linguistic theory. Lakoff (1970), Babcock (1972), Cruse (1972), Baron (1974), Shibatani (1976), Olszewska (1986), Levin and Rappaport Hovav (1994) and Stalmaszczyk (1997) include causation as a basic notion in syntactic and semantic analysis. In English, the causative relation can be realised in a number of surface structure expressions, which are typically divided into two groups: lexical causatives (causative verbs) and syntactic structures. In the latter group, one finds periphrastic constructions with causative verbs: causative cause, have, get, let and make.

Baron (1974, p. 308) says that seven different types of complements occur with periphrastic causative verbs in Modern English, that is, the infinitive, present participle, finite clause, noun, adjective, past participle and locative. However, not every periphrastic may be used with every complement. Periphrastic causatives fall into two groups as far as their infinitival complementation is concerned: verbs taking to-infinitive and verbs occurring with bare infinitives as their complements. Because of its permissive/causative meaning, let occupies a special position among English periphrastic causatives. The most prominent causative verbs taking bare infinitive complements are make and let. Both of them 
have near-paraphrases taking full infinitives (for a detailed discussion over the periphrastic causative cause, make, have, get and let see Baron, 1974, p. 308; and Olszewska, 1986, p. 63).

\section{Social motivation in the use of causative get}

Now, we seem to be prepared to start our material investigation of how get-related causative constructions happen to be distributed in F. Scott Fitzgerald's The Beautiful and Damned and Tender Is the Night. Our basic expectation is that we can find some motivation for the get-constructions, motivation being extra-linguistic in its nature. What we mean is that our research question goes beyond structural and formal considerations. In other words, we believe that the motifs for triggering the use of causative get are of social, rather than structural, nature. Generally, we opt for the kind of sociolinguistics which presents language not as system of arbitrary systemic relations, but as a record of human conceptualization and experience. What this means in practice results in justifying (motivating) linguistic forms and structures (here: periphrastic causative get) not by a purely linguistic syntagmatic relations, but by extra-linguistic considerations, such as gender of the interlocutors.

The two aforesaid novels will serve as our material basis. Our analysis will focus only on the dialogued passages occurring in the novels, as this will ensure that the causative constructions are produced by one of the two genders and will be directed to representatives of one or two genders. By using the two novels as our material basis, the aim of our research is not to analyse the actual utterances produced by men and women, as those found in various corpora, but to see how the causative get is operated by Fitzgerald and whether his characters, males and females use the verb differently. Our major goal is to investigate whether the gender of the interlocutors influence in any way the occurrence of the causative get.

\section{Analysis}

\section{Data under examination}

Our data have been derived from the two novels by F. Scott Fitzgerald: The Beautiful and Damned and Tender is the Night and they comprise 20 occurrences of the periphrastic causative get. ${ }^{2}$ As far as the former novel is concerned, among the get occurrences analysed, one finds 9 get occurrences. With regard to the latter novel, our scrutiny refers to 11 cases of get. The specific examples are presented in the Appendix, Tables 2-3 (Table 2 in the Appendix refers to the causative get found in the former novel, whereas Tables 3 in the Appendix refers to the causative get found in the latter one).

\section{Data distribution}

In The Beautiful and Damned, get is used 9 times; 8 occurrences appear in the dialogued passages (Table 2 in the Appendix), whereas in Tender Is the Night, the verb is used 11 times; 9 cases of the verb are found in the dialogued passages (Table 3 in the Appendix). Therefore, in total, the causative get is used 20 times in both novels: 3 times in the narrated passages and 17 times in the dialogued ones. With regard to the dialogued occurrences, get is used by a male character 13 times and is addressed 10 times to another male character, and 3 times to a female character. Female characters use causative get 4 times: 4 times to male characters and once to a female character; this is so, because one of the

\footnotetext{
2 We should stress the fact that our analysis refers only to those constructions where the causer and the causative verb are accompanied by the object of causative action (causee) and the complement of the causative verb, and as in the examples: Air'll get the rotten nicotine out of your lungs (Fitzgerald, 1922, p. 30). Therefore, examples with one or more of the above-mentioned elements missing have been disregarded. Moreover, it should be stressed that some of the analysed verbs may receive causative or non-causative interpretation, as in the example: This is just a change-the situation is a father's problem with his son-the father can't get the son up here (Fitzgerald, 1934, p. 355). Then "getting the son up here" could be interpreted as "bringing the son here" or "causing someone to bring the son here".
} 
occurrences is addressed both to male and female characters. So, the above-mentioned observations may be summarised by means of the following symbols:

$\begin{array}{lll}\text { Get } 20 \mathrm{x}>3 \mathrm{~N}+17 \mathrm{D} & \\ \mathrm{M}: 13 & >\mathrm{M} / \mathrm{M}: 10 & \mathrm{M} / \mathrm{F}: 3 \\ \text { F: } 4 & >\mathrm{F} / \mathrm{M}: 4 & \text { F/F: } 1\end{array}$

Moreover, our analysis with regard to the causative get (Tables 2-3 in the Appendix) reveals certain generalizations as found in the dialogued passages of both novels:

$$
\text { (1) get } \mathrm{M}(13) \sim \mathrm{F}(5) \quad 2.6 \mathrm{x}
$$

Causative get is used 13 times by male characters, whereas it is used 5 times by females ones. Therefore, male characters use causative get 2.6 times more frequently than female ones.

$$
\text { (2) get M/M (10) M/F (3) } 3.33 \mathrm{x}
$$

Causative get is used 10 times by a male character addressing another male character, whereas it is used 3 times by a male character addressing a female character. Therefore, male characters use causative get 3.33 times more frequently when addressing other male characters than female characters.

$$
\text { (3) get F/M (4) F/F (1) } \quad 4 \mathrm{x}
$$

Causative get is used 4 times by a female character addressing a male character, whereas it is used once by a female character addressing another female character. Therefore, female characters use causative get 4 times more frequently when addressing male characters than female characters.

So, our expectation is, at least at this stage, that, pragmatically, we can talk about something like "masculine" get, which is that as a causative verb, get is a characteristic of men's talk as well as the expected form while female characters address male ones. Let us go into specific contexts to see whether or not this could be so. As a check-up on our prediction, we will examine all the getoccurrences in both novels in terms of the speaker-hearer power relation, speaker's mood as well as the speaker's attitude expressed. By doing so we would like to investigate whether masculinity associated with causative get in the two novels by Fitzgerald can be associated with some other traits.

As evidenced in Table 1, which presents the specific characterisation of the causative get-contexts, there does not seem to be any particular pattern in either the speaker's mood or the speaker's attitude expressed that would trigger the use of causative get. The speaker's mood can be anything from relaxed and confident through good and jovial to excited and irritated, whereas the speaker's attitude expressed towards what is being talked about has an equally vast range, from negative through neutral to positive. In other words, the mood exemplified by the speaker can be as desirable as jovial and as low as depressed. A similar observation can be dropped in regard to the attitude that the speaker expresses towards the subject matter of a given dialogue: the attitude can be as much mocking or disapproving as favourable and approving, with neutrality possible as well. At the same time, as we see in the Table above, no correlations between the type of the speaker's mood and the type of the speaker's attitude expressed towards what is being talked about have been found. 
Table 1. Specific characterisation of causative get-contexts

\begin{tabular}{|c|c|c|c|c|c|c|}
\hline \multirow{2}{*}{$\begin{array}{l}\text { Tablel } \\
\text { No. }^{3}\end{array}$} & \multirow{2}{*}{$\begin{array}{l}\text { Gender of } \\
\text { interlocutors } \\
\text { and object of } \\
\text { causative } \\
\text { action }\end{array}$} & \multicolumn{3}{|c|}{ Speaker-hearer power relation } & \multirow[t]{2}{*}{ Speaker's mood } & \multirow{2}{*}{$\begin{array}{c}\text { Speaker's attitude } \\
\text { expressed }\end{array}$} \\
\hline & & Superiority & Equality & Inferiority & & \\
\hline $2 / 1$ & M/M-NH4 & $\mathrm{X}$ & & & Relaxed & Positive/Favourable \\
\hline $2 / 2$ & M/F-MF & $\mathrm{X}$ & & & Nervous & Negative/Critical \\
\hline $2 / 3$. & F/M-F & $\mathrm{X}$ & & & Relaxed & Negative/Mocking \\
\hline $2 / 4$. & M/M-NH & $x$ & & & Confident/Excited & Positive/Approving \\
\hline $2 / 5$ & M/M-NH & $X$ & & & Confident/Excited & Negative/Disapproving \\
\hline $2 / 6$ & M/M-NH & $\mathrm{X}$ & & & Confident & Positive/Approving \\
\hline $2 / 7$. & $\mathrm{M} / \mathrm{F}-\mathrm{M}$ & $\mathrm{X}$ & & & Irritated/Depressed & Neutral/Carefree \\
\hline $2 / 9$. & $\mathrm{M} / \mathrm{M}-\mathrm{F}$ & $\bar{X}$ & & & Jovial & Positive/Favourable \\
\hline $3 / 1$ & F/M-M & $\bar{x}$ & & & Reluctant & Positive/Encouraging \\
\hline $3 / 2$. & F/MF-NH & & & $\mathrm{X}$ & Anxious/Tired & Negative/Doubtful \\
\hline $3 / 3$. & M/M-M & $\mathrm{X}$ & & & Tense & Positive/Determined \\
\hline $3 / 5$. & M/M-NH & $\mathrm{X}$ & & & Relaxed/Casual & Neutral \\
\hline $3 / 6$. & F/M-F & $\mathrm{X}$ & & & Anxious/Tense & Positive/Favourable \\
\hline $3 / 7$ & M/M-M & $\mathrm{X}$ & & & Tense & Neutral \\
\hline $3 / 8$. & M/M-M & $\mathrm{X}$ & & & Tense & Positive/Favourable \\
\hline $3 / 9$. & M/M-M & $X$ & & & Tense/Anxious & Positive/Favourable \\
\hline $3 / 11$. & $\mathrm{M} / \mathrm{F}-\mathrm{NH}$ & $X$ & & & Good & Neutral \\
\hline
\end{tabular}

However, when it comes to the speaker-hearer power relation, the speaker's superiority seems to definitely outnumber the inferiority cases. This would mean that the causative get can more readily be found when the speaker assumes power position rather than when the speaker exemplifies the inferior position. As one can observe, what is important is that the superiority in most cases equals masculinity.

3 Our numbering here corresponds to the order of the get examples in Table 2 and 3 in the Appendix. The specific examples are, then, referred to by the table and the occurrence number.

${ }^{4}$ The above-mentioned symbols should be understood as follows: (M) - male, (F) - female, (MF) - male and female, $(\mathrm{NH})$ - non human, (/) - X speaks to $\mathrm{Y},(-)$ indicates the object of causative action (causee). The same symbols will be used in the Case Studies and in Appendix. Additionally, in the Case Studies and the Appendix we find the following symbols: (D) - dialogued occurrence, (N) - narrated occurrence, (na) - no speaker/hearer relation, (UH) - unspecified human. 
This would be in line with what Tannen (1990) claims, namely, that men's speech often reflects their power. For the reasons stated above, we propose that in the case of causative get, the masculinity of the speakers can, as a rule, be viewed in a strong and direct connection with their superiority; similarly, their superiority cannot be considered without associating it with masculinity.

Of the 4 occurrences of the causative get used by women, 3 of them are used by women having a superior status. Since superiority is so strongly connected with masculinity, we propose that those female characters also possess some masculine traits or they simply use "masculine" language, while addressing males, as to accommodate to the manner men speak. Therefore, we postulate that the causative get used in the two novels should, in most cases, be labelled not only as "masculine", but also "superior" get. As this finding seems to be of a well-defined pattern, let us have a look to 3 specific contexts and analyze them in terms of (i) situational context, (ii) the intended pragmatic import and (iii) contextual assessment. Because the causative get is mostly used when the speaker's position is superior (with only one case of the verb when the speaker assumes an inferior position), we shall only analyze the superiority cases in our Case Studies.

\section{Case Studies}

\section{Case study 1}

\begin{tabular}{|c|c|c|c|}
\hline $\begin{array}{c}\text { Table/ } \\
\text { Item }\end{array}$ & $\begin{array}{c}\text { Causative get occurrence in The Beautiful and } \\
\text { Damned by F. Scott Fitzgerald }\end{array}$ & Page & Object of causative action \\
\hline $2 / 1$. & (...) Air'll get the rotten nicotine out of your lungs. \\
$(. .)$. & 30 & D-M/M-NH \\
\hline
\end{tabular}

\section{Situational context}

The quotation is part of a dialogue between Anthony Patch and Richard Caramel. The quoted sentence is generated by the former character. The conversation takes place on a freezing, winter afternoon in New York City. Anthony Patch walks along Forty-Second Street when he unexpectedly encounters Richard Caramel emerging from the Manhattan Hotel barber shop. Richard Caramel wears a fashionable, sheep-lined coat and a soft, brow hat. He stops Anthony, slaps him on the arms and shakes hands with him. Richard mentions that he has recently been working a lot on his novel in a cold room which makes him fear that he might get pneumonia as a result. Richard seizes Anthony's arm and they walk briskly up Madison Avenue. When Anthony asks Dick where they are going to, Dick replies: "Nowhere in particular" (Fitzgerald, 1922, p. 29). Dick's face is all red from the cold. They pass FortyFifth Street and slow down slightly. Both of them light cigarettes.

Anthony suggests that they walk up to the Plaza and have an egg-nog. Furthermore, Anthony asserts that walking up to the Plaza will be good for Dick, and additionally, the air will get the nicotine out of Dick's lungs. Anthony also says that Dick will be able to tell him about his book on the way to Plaza. The two men reach Fiftieth Street and turn over toward Madison Avenue. They continue their conversation, with Gloria Gilbert being its main topic. They have a little argument, but they reconcile by the time they reach the Plaza. It is the dusk when they enter Plaza where they have the egg-nog.

\section{Pragmatic import}

Richard Caramel is happy to meet Anthony Patch. He stops Anthony enthusiastically. Nevertheless, when he slaps Anthony on his arms, he does it "more from a desire to keep himself warm than from playfulness" (ibid.). Another reason why Dick is happy is that he has been working a lot and he is pleased with the results of his work. He says: "Done some good work on my novel" (ibid.). Dick believes

5 This is an excerpt from our Table 2 where we present all our get-occurrences. Similarly, whenever we offer a quotation in subsequent Case Studies, we also refer to our Tables 1-2. 
that he occasionally needs to go out, meet other people and talk to them. He says: "I have to get out once in a while" (ibid.).

While meeting Dick, Anthony seems to be the person who dominates the conversation and emphasizes his superior position by means of both words and gestures. After Dick seizes Anthony's arm, Anthony withdraws his arm gently, which may be interpreted as a signal that he will not allow Dick to dominate him or exert control over him. What is more, Anthony says sarcastically: "I don't mind carrying you, Dick, but with that coat—", which again can be construed as not giving consent to Dick for controlling the situation (Fitzgerald, 1922, p. 30). Moreover, in response to Dick's dilemmas, Anthony does not show understating or offer any support, but he only grunts, which again marks his somewhat disrespectful attitude towards Dick. The two characters light up cigarettes, which may be understood as a way of easing their tension or indulging themselves.

It should be mentioned that it is the character that has the stronger position, Anthony, who suggests going to the Plaza. The very quotation in question may be interpreted as Anthony's advice which is offered to Dick. One normally expects that a suggestion or advice is usually given by the party who enjoys more power or authority in a relation, rather than the one that having an inferior position. This fact would again prove Anthony to be the more powerful interlocutor. The intended, pragmatic result of the quotation is actually to make Dick go for a drink with Anthony, and not really to cause Dick's lungs to clear from nicotine. The suggestion that a walk and fresh air will do Dick good is, therefore, only a tool, if not a mere pretext, for achieving Anthony's goal. This goal would be having an alcoholic drink. Dick accepts Anthony's proposal which once more confirms Anthony's dominance in the relation. The hearer's response to the speaker's linguistic stimulus is, therefore, fully compatible to the intended one.

That this could be so can be further evidenced with some more phrases in the dialogue. Anthony "magnanimously" lets Dick talk about his book all the way to the Plaza. In reply, Dick says: "I don't want to if it bores you. I mean you needn't do it as a favour", which again portrays Dick as a weaker character (ibid.). Furthermore, it is Anthony who offends Dick when they talk about the types of women for whom Dick has liking. When Dick wants to react after he has been offended, Anthony does not let him do so by interrupting him "ruthlessly" (Fitzgerald, 1922, p. 31). Dick complains to Anthony thusly: "You talk sometimes as though I were a sort of inferior" (ibid.). This again confirms the observation that Anthony, in his acting towards Dick, shows superiority or at least Dick feels inferior.

\section{Contextual assessment}

The context clearly demonstrates that it is Anthony who assumes the more powerful, dominant position throughout the dialogue. This can be well evidenced both by Anthony's language and acting. Therefore, the kind of causative get that we see in this Case Study is clearly masculine and serves the purposes of imposing the superiority position by the speaker on the hearer.

\section{Case study 2}

\begin{tabular}{|c|c|c|c|}
\hline $\begin{array}{c}\text { Table/ } \\
\text { Item }\end{array}$ & $\begin{array}{c}\text { Causative get occurrence in The Beautiful and Damned by } \\
\text { F. Scott Fitzgerald }\end{array}$ & Page & $\begin{array}{c}\text { Object of causative } \\
\text { action }\end{array}$ \\
\hline $2 / 2$. & (...) Do you want to get us pinched?' & 145 & D-M/F-MF \\
\hline
\end{tabular}

\section{Situational context}

The quotation is part of a dialogue between Anthony Patch and Gloria Patch. The quoted sentence is produced by Anthony. The conversation takes place when Anthony and Gloria Patch go by car to the countryside to find a house they could rent. Gloria asks Anthony to let her drive the car. Anthony is not in favour of this proposal as he doubts Gloria's driving skills. Nevertheless, he agrees, they change seats and Gloria takes the wheel. The car leaps ahead and curves "retchingly about a standing milk-wagon" (Fitzgerald, 1922, p. 145). The driver of the milk-wagon stands up on his seat and bellows after them. 
Anthony tries to warn Gloria that an inexperienced driver should not go over twenty miles an hour for the first five thousand miles. Gloria nods briefly, but she fails to obey Anthony's warnings and she slightly increases the speed. Soon afterwards, Anthony makes another attempt to make Gloria slow down. He mentions to Gloria that she has ignored a road sign with a speed limit. He asks rhetorically if she wants them to get arrested for speeding. Gloria replies to Anthony that he always exaggerates. They hastily pass a policeman that has swerved into view. Anthony asks Gloria about the policeman: "See him?" (Fitzgerald, 1922, p. 146). Anthony continues warning his wife to drive carefully. He tells her to mind railroad tracks and approaching automobiles. Eventually, he insists on taking the wheel and he succeeds.

\section{Pragmatic import}

When Gloria asks Anthony to let her drive the car, he looks at her suspiciously and doubts her skills. He asks Gloria: "You swear you're a good driver?" This seems to confirm the stereotype that women are bad drivers, or it may simply indicate that Anthony doubts Gloria's skills. Anthony's unfavourable attitude towards the prospect of Gloria driving the car finds reflection in Anthony's language and behaviour. For instance, when he stops the car in order to let Gloria drive it, he does it cautiously, as if he wanted to express his uncertainty and reluctance. The very idea that a woman should drive the car may also, in Anthony's eyes, undermine his superior, masculine position. Soon after he allows Gloria to drive, he realizes that he has made a great mistake in relinquishing control over the car. Yet, Anthony marks his strong, dominant position by scolding Gloria and giving her frequent and numerous warnings and indications about driving.

The linguistic means that seem to confirm Anthony's dominant position include the use of the imperative: "Remember now!" or the verb ought in: "The man said we oughtn't to go over twenty miles an hour for the first five thousand miles" (Fitzgerald, 1922, p. 145). As to emphasize his superior position, he also makes use of rhetorical questions, such as "See that sign?" (ibid.). The quoted phrase itself: "Do you want to get us pinched?" is itself a rhetorical question. Its intended, pragmatic effect is to scare the hearer and in consequence cause her to slow down. This sharply contrast with the achieved pragmatic effect (import), as the hearer's response to the speaker's linguistic stimulus is just opposite, that is, the hearer does not obey the speaker's commands and continues reckless driving. Gloria says that Anthony simply exaggerates and persists in her speedy ride.

The dominant position of the speaker can be further evidenced with some more data. Anthony continues trying to exert control over Gloria. He does it, for example, by asking another rhetorical question. He asks Gloria whether she has seen the policeman that they passed hastily. Moreover, he assumes the position of reasonable and responsible person as he warns Gloria of railroad tracks and points out approaching cars. Reproving Gloria and giving her confirms his powerful status. Eventually, as he gets his own way, his masculine, superior position is not endangered. He insists on taking the wheel and Gloria finally obeys.

\section{Contextual assessment}

The context clearly demonstrates that the speaker of the quotation under examination enjoys dominant and more powerful position throughout the dialogue than the hearer. This is well demonstrated by the language used by the speaker as well as by his non-verbal signals. Hence, our scrutiny of the causative get in the present Case Study clearly indicates that we deal with masculine get which is used in order to impose the superiority position by the speaker on the hearer. 


\section{Case study 3}

\begin{tabular}{|c|c|c|c|}
\hline $\begin{array}{l}\text { Table/ } \\
\text { Item }\end{array}$ & $\begin{array}{c}\text { Causative get occurrence in Tender is the Night by F. } \\
\text { Scott Fitzgerald }\end{array}$ & Page & $\begin{array}{l}\text { Object of causative } \\
\text { action }\end{array}$ \\
\hline $6 / 6$. & $\begin{array}{c}\text { (...) Plenty for everything, and it ought to be used to get } \\
\text { Nicole well.' }\end{array}$ & 318 & $\mathrm{D}-\mathrm{F} / \mathrm{M}-\mathrm{F}$ \\
\hline
\end{tabular}

\section{Situational context}

The quotation is a part of a dialogue between Dick Diver and Baby Warren. The quoted sentence is produced by the latter character. Anthony encounters Baby in the doorway of the Excelsior in Rome. Baby says that she thought Dick was in America. Dick tells her that he was in America, but he has returned to Europe via Naples. They have dinner together. At Baby's request, Dick tells her about recent events in his life. As the conversation continues, Baby suggests that Dick and Nicole move away, because a change would be desirable for Nicole. Dick reminds Baby that it was her idea to buy the clinic in Switzerland where Dick practises, so he does not understand why they should move away. Baby says that the decision on buying the clinic resulted from the fact that Dick was "leading that hermit's life on the Riviera" (Fitzgerald, 1934, p. 317). Baby suggests that they move, for example, to London, as "the English are the best-balanced race in the world" (ibid.). Baby continues to persuade Dick to move to England with Nicole. She says that money is not a problem as there is plenty of it and it should be used to treat Nicole. Dick rejects Baby's idea.

\section{Pragmatic import}

When Dick meets Baby in the Excelsior, she tries to establish the dominant position over Dick from the very beginning of the dialogue. She demands, not asks him to tell her about recent events in his life. She frowns at Dick, which may be interpreted as a sign of dissatisfaction and her dominant status. She says that she does not want to give advice or interfere with Dick and Nicole's affairs, yet her words about Nicole's prospects may be interpreted just to the contrary. She says: “Dick, I don't pretend to advise you or to know much about it but don't you think a change might be good for her - to get out of that atmosphere of sickness and live in the world like other people?" (Fitzgerald, 1934, p. 317). Baby appears to be very shallow and self-confident, but she is persistent and obstinate at the same time. While talking to Dick about the national character of the English, she strongly disagrees with Dick's opinion on that issue. Baby is very anxious to make sure that her sister, Nicole, is treated well. Baby is a wealthy and powerful woman and she seems to take advantage of that fact.

The intended pragmatic effect of the quotation is to take Nicole from Franz and Dick's clinic and to settle her in England. The money will be an instrument necessary to attain this goal. Baby knows that her position enables her to influence and manipulate people, including Dick. Dick, on the other hand, knows that he is dependent on Baby. He is aware of the fact that he became a co-owner of the clinic in Switzerland only due to Baby's financial support. Albeit Dick agreed to acquire the Swiss clinic with the Warrens' money, he had a feeling that Baby's message, directed to him, was: "We own you, and you'll admit it sooner or later. It is absurd to keep up the pretense of independence" (Fitzgerald, 1934. p. 261). This, once more, confirms that in the relation between Dick and Baby, it is the latter individual who has the dominant position. Yet, Dick rejects Baby's idea. Therefore, Dick's response to the linguistic stimulus produced by Baby is just opposite to the intended one. Dick does not agree to move to England. In other words, Baby's ideas contrast sharply with the achieved pragmatic effect (import).

Nevertheless, Baby remains the more powerful character and her dominant status can be further evidenced with some other data from the novel. For instance, when Dicks gets arrested because of fighting with a man who happens to be an Italian policeman, ironically, the only person he can resort to is Baby Warren. Due to her persistence at the Consulate, she accomplishes Dick's release. 


\section{Contextual assessment}

The context evidently shows that the speaker in the quotation (Baby Warren) has a stronger position than the hearer (Dick Diver). Baby's superior status is realized by means of both verbal and non-verbal signals. Our analysis of the causative get in the present Case Study clearly demonstrates that we deal with a "masculine" get, used by a female character. It may be speculated that the "masculine" get in the present Case Study, which on other occasions is regularly used by male characters in the novel, is employed by the female speaker to maintain or emphasize her superior position over the male hearer.

\section{Conclusion}

Our analysis refers mostly to the dialogued passages in the two novels. Generally, what we have found is that there is a clear pattern of how F. Scott Fitzgerald uses the causative get in his two novels in focus here. This patter is evidently of social nature. Get is, first of all, a characteristic of men's talk, but it is also the expected form while female characters address male ones - this may be because females, while addressing males, tend to use "masculine" language; hence we label it as "masculine" get. Moreover, we have discovered that there does not seem to be any particular pattern in either the speaker's mood or the speaker's attitude expressed that would trigger the use of the causative verb in question. However, what seems to be a well-defined tendency, when it comes to the speaker-hearer power relation, is that the speaker usually assumes a more superior position than the hearer when he or she uses the causative verb. What is very important is that the superiority in most cases is strongly associated with masculinity and it should always be viewed in relation to masculinity. Hence, we label the causative get not only as "masculine" but also as "superior".

As can be seen above, we have established some very clearly-defined patterns as to the occurrence of the causative get in the dialogued passages in the two novels. One may be interested, why for the two novels, the above-mentioned patters are clearly established? To what extent the established pattern is caused by the fact that the author of the novels was a male? Or perhaps he was a skilful observer and masterfully depicted the language used by the two genders? It goes without saying that it very difficult, if not impossible at all, to answer those questions satisfactorily. Definitely, it would be interesting to compare our finings with other material, be it, fiction or actual utterances gathered in corpora presenting the language of the first half of twentieth century. This could undoubtedly shed some more light on the problem.

\section{References}

Arliss, L. P. (1991). Gender Communication. Englewood Cliffs, NJ: Prentice-Hall.

Babcock, S. (1972). Periphrastic causatives. Foundations of Language, 8, 30-43.

Baron, D. (1986). Grammar and Gender. New Haven: Yale University Press.

Baron, N. S. (1974). The structure of English causatives. Lingua, 33, 299-342.

Brend, R. (1975). Male-female Intonation Patterns in American English. In Thorne, B. and Henley, N. (Eds.), Language and Sex: Difference and Dominance (p. 84-88). Rowley, MA.

Brower, D., Gerritsen, M. \& de Haan, D. (1979). Speech Differences between Women and Men: On the Wrong Track? Language in Society, 8, 33-50.

Cameron, D., McAlinden, F., \& O'Leary, K. (1989). Lakoff in Context: The Social and Linguistic Functions of Tag Questions. In Coates, J. \& Cameron, D. (Eds.), Women in Their Speech Communities (p. 74-93). London: Longman.

Coates, J. (1996). Women Talk: Conversation between Women Friends. Oxford: Blackwell.

Crystal, D. (1987). The Cambridge Encyclopedia of Language. Cambridge: Cambridge University Press.

Cruse, D. A. (1972). A note on English causatives. Linguistic Inquiry, 3, 522-528.

Dubois, B. L. \& Crouch, I. (1975). The Question of Tag Questions in Women's Speech: They Don't Really Use More of Them, Do They? Language in Society, 4, 289-94. 
Eckert, P. and McConnell-Ginet, S. (2003). Language and Gender. Cambridge: Cambridge University Press.

Fitzgerald, F. S. (1922). The Beautiful and Damned. Hazleton, PA: The Pennsylvania State University [published as A Penn State Electronic Classics Series Publication].

Fitzgerald, F. S. (1934). Tender Is the Night [published as Planet eBook].

Gołąbek, R. (2015). English Periphrastic Causative Constructions as Gender-Based Expressions of Human Experience in F. Scott Fitzgerald's Novels 'The Beautiful and Damned' and 'Tender Is the Night'. Lublin: Uniwersytet Marii Curie-Skłodowskiej w Lublinie, unpubl. PhD Dissertation.

Grishaver, J.L. (1997). The Bonding of Isaac: Stories and Essays about Gender and Jewish Spirituality. Los Angeles: Alef Design Group.

Hartman, M. (1976). A descriptive study of the language of men and women born in Maine around 1900 as it reflects the Lakoff hypothesis in "Language and women's place." In. Dubois, B. L \& Crouch, I. (Eds.), The sociology of the languages of American women (p. 53-62). San Antonio, TX: Trinity University Press.

Kipers, P. S. (1987). Gender and Topic. Language and Society, 16, 543-57.

Lakoff, G. (1970). Irregularity in syntax. New York: Holt, Rinehart, and Winston.

Lakoff, R. (1973). Language and Woman's Place. Language in Society, 2, 45-80.

Lakoff, R. (1975). Language and Woman's Place. New York: Harper \& Row.

Levin, B. and Rappaport Hovav, M. (1994). A Preliminary analysis of causative verbs in English. Lingua 92, 35-77.

Litosseliti, L. (2013). Gender and Language: Theory and Practice. Oxon \& New York: Routledge.

Mehl, M. R. \& Pennebaker, J. W. (2003). The sounds of social life: A psychometric analysis of students' daily social environments and natural conversations. Journal of Personality and Social Psychology, 84, 857-870.

Mulac, A. and Lundell, T.L., 1986. Linguistic contributors to the gender-linked language effect. Journal of Language and Social Psychology, 5, 81-101.

Olszewska, T. (1986). Causativity as a linguistic phenomenon. A study based on English and Polish. Lublin: UMCS.

Pilkington, J. (1998). “Don't Try and Make Out that I'm Nice!” The Different Strategies Women and Men Use when Gossiping. In Coates, J. (Ed.), Language and Gender: A Reader. Oxford: Blackwell.

Poole, M. E. (1979). Social class, sex and linguistic coding. Language and Speech, 22, 49-67.

Ritti, A. (1973). Social junctions of children's speech (Doctoral dissertation, Columbia University, Teachers College, 1973). Dissertation Abstracts International, 34, 2289B.

Romaine, S. (1999). Communicating Gender. Mahwah, NJ: Lawrence Erlbaum.

Salzmann, Z. (1993). Language, culture and society: an introduction to linguistic anthropology. Oxford: Westview Press.

Shibatani, M. (Ed.) (1976). Syntax and Semantics VI. The Grammar of causative constructions. New York: Academic Press.

Stalmaszczyk, P. (1997). Causative verbs: properties and representations (from Generative Semantics to the Minimalist Program). In Gussmann, E. and Szymanek, B. (Eds.), PASE papers in literature, language and Culture (p. 535-546). Lublin: The University Press of the Catholic University of Lublin.

Tannen D. (1990). You Just Don't Understand: Women and Men in Conversation, New York: HarperCollins Publishers Inc.

Wardhaugh, R. (2006). An Introduction to Sociolinguistic. Oxford: Blackwell Publishing Ltd.

Whorf, B. L. (1929). Language, thought, and reality: Selected writings of Benjamin Lee Whorf. Cambridge: Technology Press of MIT and John Wiley and Sons.

Włodarczyk-Stachurska, A. (2011a). Language variations vis-à-vis gender factor. In Kleparski G. A. \& Kiełtyka, R. (Eds.), Podkarpackie Forum Filologiczne. Seria: Językoznawstwo. Jarosław: Wydawnictwo Państwowej Wyższej Szkoły Techniczno-Ekonomicznej w Jarosławiu. 
Włodarczyk-Stachurska, A. (2011b). On Sociolinguistic Variation: The Case of English Women Terms. Radom: Wydawnictwo Politechniki Radomskiej.

\section{Bibliographic note}

The present paper is a revised and elaborated version of the ideas presented in the author's doctoral dissertation entitled English Periphrastic Causative Constructions as Gender-Based Expressions of Human Experience in F. Scott Fitzgerald's Novels 'The Beautiful and Damned' and 'Tender Is the Night' for details, see Gołąbek, 2015, in References).

\section{Contact}

Rafał Gołąbek

Kazimierz Pułaski University of Technology and Humanities in Radom

31 Chrobrego Str.

26-600 Radom, Poland

Rafal.Golabek@wp.pl

\section{Appendix}

Table 2. The causative get occurrences in The Beautiful and Damned by F. Scott Fitzgerald

\begin{tabular}{|c|c|c|c|}
\hline No. & Quotation & Page & $\begin{array}{l}\text { Object of } \\
\text { causative } \\
\text { action }\end{array}$ \\
\hline 1. & (...) Air'll get the rotten nicotine out of your lungs. (...) & 30 & $\mathrm{D}-\mathrm{M} / \mathrm{M}-\mathrm{NH}$ \\
\hline 2. & (...) Do you want to get us pinched?' & 145 & $\mathrm{D}-\mathrm{M} / \mathrm{F}-\mathrm{MF}$ \\
\hline 3. & $\begin{array}{l}\text { (...) And I'll bet a hat if he's gotten an idiot to sit and be stupid with him he's } \\
\text { tearing out on the side with some much speedier lady.' }\end{array}$ & 149 & $\mathrm{D}-\mathrm{F} / \mathrm{M}-\mathrm{F}$ \\
\hline $4 / 5$. & $\begin{array}{l}\text { "There's the man who gets to be an assistant secretary or treasurer, gets his } \\
\text { name on our folder here, before he's thirty, and there's the man who gets his } \\
\text { name there at forty-five. (...) }\end{array}$ & $\begin{array}{l}187- \\
188\end{array}$ & $\begin{array}{l}\mathrm{D}-\mathrm{M} / \mathrm{M}-\mathrm{NH} \\
\mathrm{D}-\mathrm{M} / \mathrm{M}-\mathrm{NH}\end{array}$ \\
\hline 6. & (...) In fact, I had to get a lot of fancy stuff out of my head.' & 188 & $\mathrm{D}-\mathrm{M} / \mathrm{M}-\mathrm{NH}$ \\
\hline 7. & $\begin{array}{l}\text { (...) He probably came up to get me to wheedle some money out of } \\
\text { grandfather for his flock.' }\end{array}$ & 223 & $\mathrm{D}-\mathrm{M} / \mathrm{F}-\mathrm{M}$ \\
\hline 8. & $\begin{array}{l}\text { This occupied several hours, for it was necessary to take a few drinks in each } \\
\text { place in order to get the proprietor in the proper frame of mind to talk } \\
\text { business. }\end{array}$ & 316 & N-na-M \\
\hline 9. & $\begin{array}{l}\text { (...) We've got some pretty good stuff lined up for about eleven o'clock, when } \\
\text { the shows let out. (...) }\end{array}$ & 352 & $\mathrm{D}-\mathrm{M} / \mathrm{M}-\mathrm{F}$ \\
\hline
\end{tabular}


Table 3. The causative get occurrences in Tender Is the Night by F. Scott Fitzgerald

\begin{tabular}{|c|c|c|c|}
\hline No. & Quotation & Page & $\begin{array}{l}\text { Object of } \\
\text { causative } \\
\text { action }\end{array}$ \\
\hline 1. & Why don't you get Mr Dumphry to go with you? & 71 & $\mathrm{D}-\mathrm{F} / \mathrm{M}-\mathrm{M}$ \\
\hline 2. & $\begin{array}{l}\text { "This time he really has got everything planned out when he gets to New } \\
\text { York." }\end{array}$ & 92 & D-F/MF-NH \\
\hline 3. & I'm going over and get Freeman out of jail. & 147 & D-M/M-M \\
\hline 4. & $\begin{array}{l}\text { From time to time his mind reverted to the fact that he ought to go over and } \\
\text { get Freeman out of jail, but he shook off all facts as parts of the nightmare. }\end{array}$ & $\begin{array}{l}152- \\
153\end{array}$ & N-na-M \\
\hline 5. & $\begin{array}{l}\text { (...) I think it's because I get the first finger soapy when I make the line of my } \\
\text { side-burn, but how it gets up on top of my head I don't know.' }\end{array}$ & 267 & $\mathrm{D}-\mathrm{M} / \mathrm{M}-\mathrm{NH}$ \\
\hline 6. & (...) Plenty for everything, and it ought to be used to get Nicole well.' & 318 & $\mathrm{D}-\mathrm{F} / \mathrm{M}-\mathrm{F}$ \\
\hline 7. & $\begin{array}{l}\text { "This is just a change-the situation is a father's problem with his son-the } \\
\text { father can't get the son up here." }\end{array}$ & 355 & $\mathrm{D}-\mathrm{M} / \mathrm{M}-\mathrm{M}$ \\
\hline 8. & $\begin{array}{l}\text { (...) Count on staying two or three days, and get the boy up here if he needs to } \\
\text { be watched. (...) }\end{array}$ & 356 & $\mathrm{D}-\mathrm{M} / \mathrm{M}-\mathrm{M}$ \\
\hline 9. & (...) Or I can get him in any one of a dozen enterprises in Paris-“" & 361 & D-M/M-M \\
\hline 10. & $\begin{array}{l}\text { (...) For fifty francs, increased to a hundred as he succumbed to the idea of } \\
\text { getting her out hastily, Augustine yielded her fortress, covering the retreat } \\
\text { with stormy grenades of "Salaud!" (...) }\end{array}$ & 388 & N-na-F \\
\hline 11. & $\begin{array}{l}\text { (...) First the actress has lines to follow, then she has to get the audience's } \\
\text { attention back on herself, away from the murdered Chinese or whatever the } \\
\text { thing is. (...) }\end{array}$ & 419 & D-M/F-NH \\
\hline
\end{tabular}

